\title{
Very-Low-Dose Pegylated
} Interferon a2a Plus Ribavirin Therapy for Advanced Liver Cirrhosis Type C: A Possible Therapeutic Alternative without Splenic Intervention

\author{
Shogo Ohkoshi Satoshi Yamagiwa Masahiko Yano \\ Hiromichi Takahashi Yo-hei Aoki Yasunobu Matsuda \\ Yutaka Aoyagi \\ Division of Gastroenterology and Hepatology, Niigata University Graduate School \\ of Medical and Dental Sciences, Niigata, Japan
}

\section{Key Words}

Liver cirrhosis type C - Low-dose pegylated interferon - Ribavirin - Low platelets - Low neutrophils · Avoiding splenic intervention · Low HCV titers

\begin{abstract}
Despite the recent progress in interferon (IFN) therapies for chronic hepatitis C, liver cirrhosis remains refractory. One of the major obstacles to successful IFN therapy is low platelet count. Currently, splenic interventions, such as partial splenic embolization (PSE) or surgical splenectomy, have been applied effectively and make standard IFN therapy possible. However, there may be a group of patients with low platelet counts who can be treated without splenic intervention. We here report two patients with advanced type $C$ liver cirrhosis who were successfully treated using very-low-dose pegylated interferon a2a plus ribavirin. One patient had a very low platelet count $\left(2.5 \times 10^{4} / \mu \mathrm{l}\right)$ due to splenomegaly before treatment. However, pretreatment serum HCV titers were low in both patients and early viral responses were obtained in both. Because PSE or splenectomy may still have some safety concerns, this attenuated IFN treatment protocol can be an alternative therapeutic option for patients with advanced type $\mathrm{C}$ liver disease, but good virological factors for sustained virological response.
\end{abstract}




\begin{tabular}{|c|c|c|c|}
\hline $\begin{array}{r}\text { Case Reports in } \\
\text { Gastronterolagy }\end{array}$ & $\begin{array}{l}\text { Case Rep Gastroenterol 2010;4:261-266 } \\
\text { DOI: } 10.1159 / 000318742\end{array}$ & Published online: July 28, 2010 & \begin{tabular}{|l} 
@ 2010 S. Karger AG, Basel \\
ISSN 1662-0631 \\
www.karger.com/crg
\end{tabular} \\
\hline
\end{tabular}

\section{Introduction}

Recent progress in the treatment of chronic hepatitis $C$ has been outstanding [1-4]. Pegylated interferon a (PEG-IFN) was developed in order to ensure sustained exposure with once-weekly dosing and offers improved convenience with a better adverse effects profile. Ribavirin accelerates clearance of virus by IFN and improves treatment outcomes. PEG-IFN plus ribavirin treatment can currently achieve sustained virological response (SVR) even in about $50 \%$ of refractory patients with genotype $1 \mathrm{~b}$ and high viral titers [2-4]. However, the SVR rate for PEG-IFN plus ribavirin treatment remains low in patients with liver cirrhosis [5-8]. In addition, a high rate of severe adverse effects is seen, and discontinuation of treatment reportedly occurs in about $10-25 \%$ of patients [5-7]. There is thus a conflict between the high risk of hepatocarcinogenesis and liver failure, which are urgent indications for therapy, and low therapeutic outcome.

One of the major obstacles to therapy in patients with type $\mathrm{C}$ hepatic cirrhosis are the low platelet counts which IFN treatment inevitably lowers further. Partial splenic embolization (PSE) has recently become more commonly applied to increase platelet counts and make standard IFN treatment feasible [9-15], and there has been much progress in the procedure, ensuring that it can be performed safely [9-13]. However, because of the level of skill required, it cannot be performed with equal safety in every facility. In addition, certain risks of severe complications remain $[9,14,15]$. Thus there is an urgent need for a new IFN protocol for the specific subgroup of patients that can possibly avoid the use of medical or surgical splenic intervention.

We performed such an attenuated protocol in two advanced liver cirrhosis patients, one with thrombocytopenia and one with neutropenia. We achieved SVR due to low $\mathrm{HCV}$ titers before treatment, and the rapid decrease in HCV titers after start of the therapy supported the continuation and completion of treatment.

\section{Patient 1}

A 61-year-old man had been followed in the outpatient clinic of Niigata University from 2003 with a diagnosis of type $\mathrm{C}$ liver cirrhosis. Ascites was identified in 2005, but was resolved with diuretics. Clinical data as of November 2007 are shown in table 1. He had low serum albumin levels. Thromboand leucocytopenia due to splenomegaly were also observed. Gastrointestinal fiberscopy showed a mild esophageal varix. HCV markers showed group 1 and a low titer $(36 \mathrm{kIU} / \mathrm{ml})$ according to qualitative Amplicore HCV Test, v.2.0. (Roche Molecular Systems, Branchburg, N.J., USA). A very low platelet count $\left(2.5 \times 10^{4} / \mu \mathrm{l}\right)$ prevented regular-dose-based IFN therapy. Considering the possibility of severe side effects of PSE or surgical splenectomy, very low doses of PEG-IFNa2a (Pegasys; $30 \mu \mathrm{g}=1 / 3$ of $90 \mu \mathrm{g}$ vial, Roche Laboratories, Nutley, N.J., USA) were started after obtaining informed consent, particularly regarding the risks of hemorrhagic side effects. This dose of IFN was administered with an interval of $10-14$ days (total 23 times, total dose $690 \mu \mathrm{g}$ ), and platelet count did not reach $<2.5 \times 10^{4} / \mu \mathrm{l}$. HCV RNA became negative (quantitative Amplicor Test, Roche Molecular systems) at 4 weeks after starting IFN, and then ribavirin (600 mg/day; Copegus, Roche Laboratories) was initiated. Laboratory data after the start of therapy are shown in figure 1 . Therapy ( 9 months in total) was continued until computed tomography revealed a solitary HCC $(\mathrm{S} 7,13 \mathrm{~mm})$. HCV RNA remained negative both during therapy and 24 weeks after the end of treatment, thus confirming SVR. HCC was successfully ablated by radiofrequency ablation and no recurrence has been identified to date (March 2010).

\section{Patient 2}

A 67-year-old woman had been followed in the outpatient clinic of Niigata University since 1998 with a diagnosis of type C liver cirrhosis. Surgical resection of HCC (S3, $20 \mathrm{~mm}$ ) was performed in 2003 and ascites were treated using diuretics in 2006. She was very interested in the progress of treatment for 
hepatitis C, particularly with regard to PEG-IFN, and she requested therapy. As she had a low titer of HCV $(110 \mathrm{kIU} / \mathrm{ml})$, we started IFN therapy from September 2007 with a dose of $90 \mu \mathrm{g}$ PEG-IFNa2a (Pegasys). As neutrophil count fell to $<750 / \mu \mathrm{l}$ the following week, the dose was reduced to $45 \mu \mathrm{g}$ and then to $30 \mu \mathrm{g}$ in November. Serum HCV RNA decreased to $<5 \mathrm{kIU} / \mathrm{ml}$ at 4 weeks and became negative 8 weeks after starting IFN. Ribavirin (Copegus, $200 \mathrm{mg} /$ day) was added from November to facilitate viral clearance. Weekly treatment with PEG-IFN (11 months in total) was continued (total dose $1,475 \mu \mathrm{g})$ until computed tomography revealed a solitary HCC (S7, $10 \mathrm{~mm}$ ). The HCC was successfully ablated using radiofrequency ablation and no recurrences have yet been identified (March 2010). HCV RNA remained negative both during therapy and 24 weeks after the end of treatment, thus indicating SVR.

\section{Discussion}

We present two patients with advanced liver cirrhosis due to HCV who were successfully treated with very-low-dose administration of PEG-IFNa2a plus ribavirin. The main reason we decided to treat these patients was the low titer of HCV, which is a good viral condition for obtaining SVR [1].

Patient 1 had severe thrombocytopenia due to splenomegaly. The pretreatment platelet count $\left(2.5 \times 10^{4} / \mu \mathrm{l}\right)$ was even below the standard level for discontinuation of PEG-IFN plus ribavirin $\left(5.0 \times 10^{4} / \mu \mathrm{l}\right)$. Currently, PSE or surgical resection is typically performed in order to raise the platelet counts, then enabling standard IFN therapy [9-13]. The increase in platelet counts after PSE may also improve the SVR rate in chronic hepatitis C patients with thrombocytopenia [11-13]. However, this procedure is associated with serious complications, such as splenic abscess, that are potentially life-threatening $[14,15]$. It should also be noted that the long-term effects of PSE and surgical splenectomy remain unknown [10]. We therefore selected a very low dose of PEG-IFN rather than splenic intervention, after obtaining careful informed consent from the patient. Fortunately, platelet count did not decrease significantly during treatment, and the treatment was well tolerated without any significant side effects.

Even with the recent progress of predicting IFN treatment outcome, it remains difficult to perfectly predict SVR [16]. The response-guided concept is thus predominant [2-4]. Virus decrease during IFN treatment can give patients motivation to adhere to therapy, while discontinuation of therapy to avoid a handful of adverse effects and therapeutic costs is possible when negative predictive value is high. Currently, early viral response (negative HCV RNA after 12 weeks of therapy) is the most commonly used marker to determine the outcome of IFN therapy [17]. Fortunately, HCV RNA in the sera became negative shortly after the start of treatment ( 4 weeks in the patient 1 and 8 weeks in patient 2). These good responses enabled the continuation of treatment and predicted the possible achievement of SVR. In other words, discontinuation of treatment should always be considered if viral decrease is insufficient. Initially, we did not administer ribavirin, deciding instead to monitor viral response to PEG-IFN, but we added ribavirin after a good viral response was obtained, and this might have accelerated viral clearance in the patients. We administered PEG-IFNa2a, which is normally used weekly, with a 10- to 14-day interval in patient 1. As PEG-IFNa2a has a longer half life than PEG-IFNa2b [18], significant effects were seen, despite the longer interval between doses.

Unfortunately, both patients developed complicating HCC. It remains uncertain whether the SVR obtained in the patients will benefit their prognosis. HCC too small to be visualized on imaging might have been present at the start of IFN treatment. If the primary goal of IFN treatment is the prevention of HCC occurrence, this was not achieved in either patient. However, SVR after HCC ablation is reported to improve 
prognosis in patients with HCC associated with hepatitis C [19-22]. Moreover, viral eradication suppresses the hepatic inflammation, lowers ALT levels and maintains hepatic reserve function. To date (March 2010), both patients have been free from HCC recurrence and quality of life has remained satisfactory.

In conclusion, an attenuated PEG-IFN protocol for patients with good viral parameters for SVR without splenic intervention should be the subject of a clinical trial in order to determine the cost-benefit balance between the risk of splenic intervention, prediction of IFN therapy outcome, and adverse effects, finally examining whether there are actual long-term clinical benefits. Careful and strict monitoring of both the antiviral effects and the appearance of severe adverse effects is absolutely necessary.

Table 1. Laboratory data at the start of PEG-IFNa2a therapy

\begin{tabular}{|c|c|c|c|}
\hline \multicolumn{4}{|l|}{ Patient 1} \\
\hline WBC & $1,700 / \mu \mathrm{l}$ & $\mathrm{TP}$ & $7.0 \mathrm{~g} / \mathrm{dl}$ \\
\hline Neutro & $71.1 \%$ & Alb & $3.2 \mathrm{~g} / \mathrm{dl}$ \\
\hline Eosino & $2.4 \%$ & T.Bil & $1.9 \mathrm{mg} / \mathrm{dl}(\mathrm{D} 0.1, \mathrm{ID} 1.8)$ \\
\hline Baso & $0.6 \%$ & AST & $67 \mathrm{IU} / 1$ \\
\hline Lympho & $20.0 \%$ & ALT & 70 IU/l \\
\hline Mono & $5.9 \%$ & ALP & $261 \mathrm{IU} / 1$ \\
\hline $\mathrm{RBC}$ & $396 \times 10^{4} / \mu \mathrm{l}$ & $\gamma$-GTP & $55 \mathrm{IU} / 1$ \\
\hline $\mathrm{Hb}$ & $10.8 \mathrm{~g} / \mathrm{dl}$ & $\mathrm{LDH}$ & $233 \mathrm{IU} / 1$ \\
\hline \multirow[t]{2}{*}{ Plt } & $2.5 \times 10^{4} / \mu \mathrm{l}$ & ChE & $113 \mathrm{IU} / 1$ \\
\hline & & BUN & $16 \mathrm{mg} / \mathrm{dl}$ \\
\hline HBsAg & - & $\mathrm{Cr}$ & $0.6 \mathrm{mg} / \mathrm{dl}$ \\
\hline HCV RNA & $36 \mathrm{kIU} / \mathrm{ml}$ & T.Chol & $158 \mathrm{mg} / \mathrm{dl}$ \\
\hline HCV serogroup & 1 & FBS & $82 \mathrm{mg} / \mathrm{dl}$ \\
\hline AFP & $7.1 \mathrm{ng} / \mathrm{dl}$ & & \\
\hline \multicolumn{4}{|l|}{ Patient 2} \\
\hline WBC & $3,170 / \mu \mathrm{l}$ & $\mathrm{TP}$ & $8.4 \mathrm{~g} / \mathrm{dl}$ \\
\hline Neutro & $24.0 \%$ & Alb & $2.6 \mathrm{~g} / \mathrm{dl}$ \\
\hline Eosino & $2.5 \%$ & T.Bil & $0.7 \mathrm{mg} / \mathrm{dl}(\mathrm{D} 0.1, \mathrm{ID} 0.6)$ \\
\hline Baso & $0.3 \%$ & AST & $39 \mathrm{IU} / 1$ \\
\hline Lympho & $63.5 \%$ & ALT & $67 \mathrm{IU} / 1$ \\
\hline Mono & $9.7 \%$ & ALP & $338 \mathrm{IU} / 1$ \\
\hline $\mathrm{RBC}$ & $391 \times 10^{4} / \mu \mathrm{l}$ & $\gamma$-GTP & $17 \mathrm{IU} / 1$ \\
\hline $\mathrm{Hb}$ & $10.1 \mathrm{~g} / \mathrm{dl}$ & $\mathrm{LDH}$ & $304 \mathrm{IU} / 1$ \\
\hline \multirow[t]{2}{*}{ Plt } & $15.8 \times 10^{4} / \mu \mathrm{l}$ & ChE & $84 \mathrm{IU} / 1$ \\
\hline & & BUN & $15 \mathrm{mg} / \mathrm{dl}$ \\
\hline HBsAg & - & $\mathrm{Cr}$ & $0.6 \mathrm{mg} / \mathrm{dl}$ \\
\hline HCV RNA & $110 \mathrm{kIU} / \mathrm{ml}$ & T.Chol & $131 \mathrm{mg} / \mathrm{dl}$ \\
\hline HCV serogroup & 1 & FBS & $88 \mathrm{mg} / \mathrm{dl}$ \\
\hline AFP & $5 \mathrm{ng} / \mathrm{dl}$ & & \\
\hline
\end{tabular}


Fig. 1. Changes in laboratory data (ALT, WBC, platelets) for patients 1 and 2 after the start of PEG-IFNa2a. The vertical axis shows the values for ALT and WBC (left) and platelets (right).

\section{Patient 1}
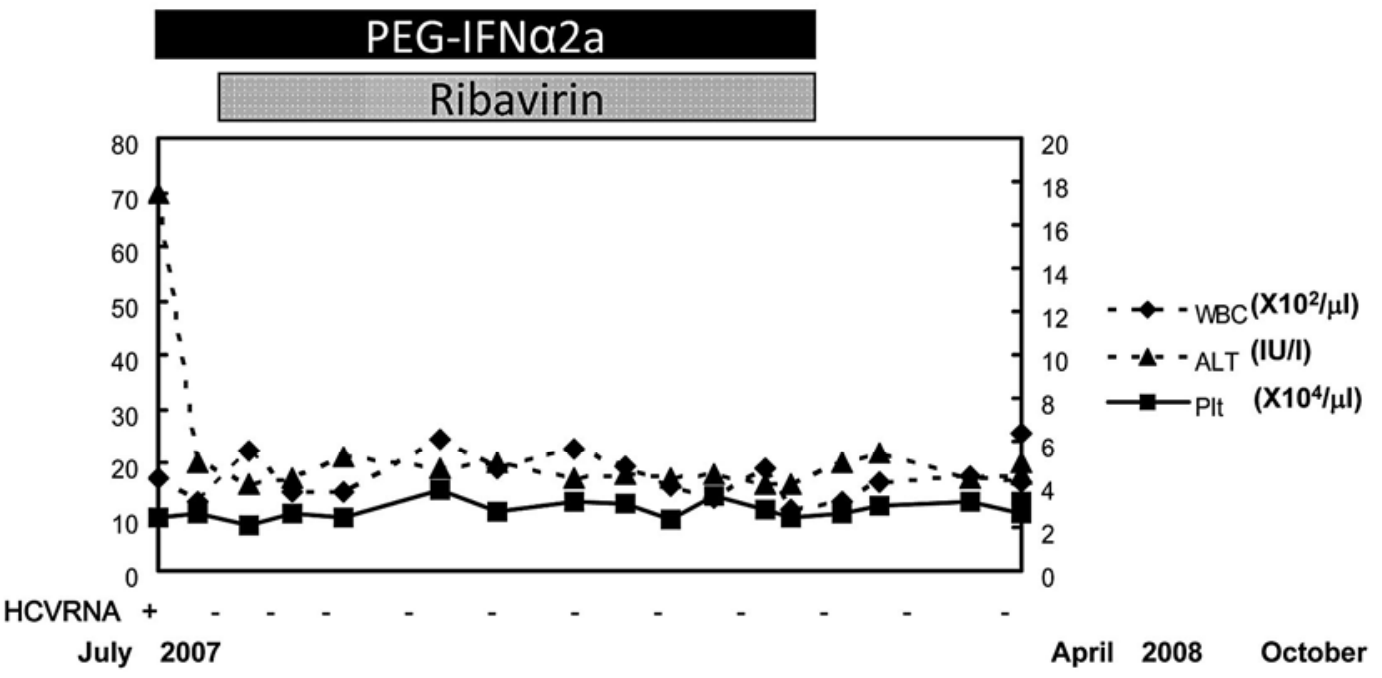

\section{Patient 2}

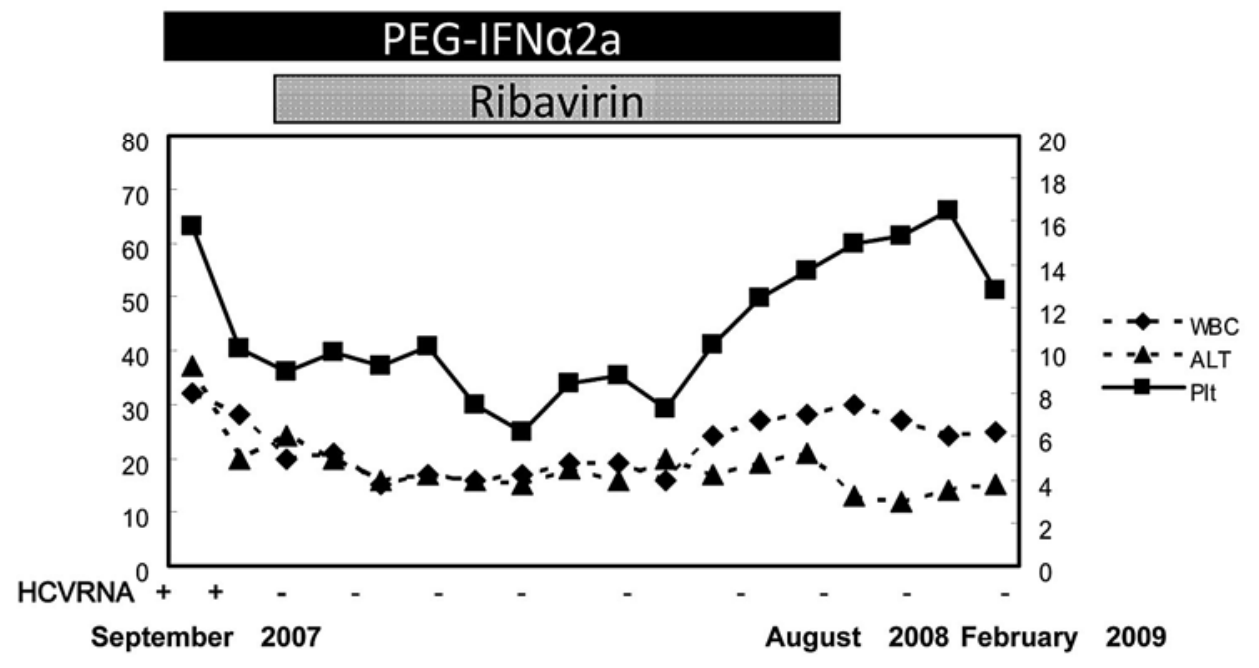




\section{References}

1 NIH Consensus Statement on Management of Hepatitis C: 2002. NIH Consens State Sci Statements 2002;19:1-46.

-2 Hayashi N, Takehara T: Antiviral therapy for chronic hepatitis C: past, present, and future. J Gastroenterol 2006;41:17-27.

- Zeuzem S: Interferon-based therapy for chronic hepatitis C: current and future perspectives. Nat Clin Pract Gastroenterol Hepatol 2008;5:610-622.

4 Heathcote EJ: Antiviral therapy: chronic hepatitis C. J Viral Hepat 2007;14(suppl 1):82-88.

5 Everson GT, Hoefs JC, Seeff LB, et al: Impact of disease severity on outcome of antiviral therapy for chronic hepatitis C: Lessons from the HALT-C trial. Hepatology 2006;44:1675-1684.

6 Helbling B, Jochum W, Stamenic I, et al: HCV-related advanced fibrosis/cirrhosis: randomized controlled trial of pegylated interferon alpha-2a and ribavirin. J Viral Hepat 2006;13:762-769.

7 Di Marco V, Almasio PL, Ferraro D, et al: Peg-interferon alone or combined with ribavirin in HCV cirrhosis with portal hypertension: a randomized controlled trial. J Hepatol 2007;47:484-491.

8 Syed E, Rahbin N, Weiland O, et al: Pegylated interferon and ribavirin combination therapy for chronic hepatitis $\mathrm{C}$ virus infection in patients with Child-Pugh Class A liver cirrhosis. Scand J Gastroenterol 2008;43:1378-1386.

9 Yoshida H, Mamada Y, Taniai N, Tajiri T: Partial splenic embolization. Hepatol Res 2008;38:225-233.

10 Ikegami T, Shimada M, Imura S: Recent role of splenectomy in chronic hepatic disorders. Hepatol Res 2008;38:1159-1171.

11 Moreno A, Bárcena R, Blázquez J, et al: Partial splenic embolization for the treatment of hypersplenism in cirrhotic HIV/HCV patients prior to pegylated interferon and ribavirin. Antivir Ther 2004;9:1027-1030.

12 Foruny JR, Blázquez J, Moreno A, et al: Safe use of pegylated interferon/ribavirin in hepatitis $C$ virus cirrhotic patients with hypersplenism after partial splenic embolization. Eur J Gastroenterol Hepatol 2005;17:1157-1164.

13 Miyake Y, Ando M, Kaji E, Toyokawa T, Nakatsu M, Hirohata M: Partial splenic embolization prior to combination therapy of interferon and ribavirin in chronic hepatitis C patients with thrombocytopenia. Hepatol Res 2008;38:980-986.

14 Sakai T, Shiraki K, Inoue H, et al: Complications of partial splenic embolization in cirrhotic patients. Dig Dis Sci 2002;47:388-391.

-15 N'Kontchou G, Seror O, Bourcier V, et al: Partial splenic embolization in patients with cirrhosis: efficacy, tolerance and long-term outcome in 32 patients. Eur J Gastroenterol Hepatol 2005;17:179-184.

16 Maekawa S, Enomoto N: Viral factors influencing the response to the combination therapy of peginterferon plus ribavirin in chronic hepatitis $\mathrm{C}$. J Gastroenterol 2009;44:1009-1015.

17 Davis GL, Wong JB, McHutchison JG, et al: Early virologic response to treatment with peginterferon alfa-2b plus ribavirin in patients with chronic hepatitis $\mathrm{C}$. Hepatology 2003;38:645-652.

18 Matthews SJ, McCoy C: Peginterferon alfa-2a: a review of approved and investigational uses. Clin Ther 2004;26:991-1025.

19 Omata M, Yoshida H, Shiratori Y: Prevention of hepatocellular carcinoma and its recurrence in chronic hepatitis $\mathrm{C}$ patients by interferon therapy. Clin Gastroenterol Hepatol 2005;3:S141-S143.

20 Ishikawa T: Secondary prevention of recurrence by interferon therapy after ablation therapy for hepatocellular carcinoma in chronic hepatitis $\mathrm{C}$ patients. World J Gastroenterol 2008;14:6140-6144.

21 Shiratori Y, Shiina S, Teratani T, et al: Interferon therapy after tumor ablation improves prognosis in patients with hepatocellular carcinoma associated with hepatitis C virus. Ann Intern Med 2003;138:299-306.

22 Mazzaferro V, Romito R, Schiavo M, et al; HCC Italian Task Force: Prevention of hepatocellular carcinoma recurrence with alpha-interferon after liver resection in HCV cirrhosis. Hepatology 2006;44:1543-1554. 